\title{
The southernmost record of a Neuryurini Hoffstetter, 1958 (Mammalia, Xenarthra, Glyptodontidae)
}

\author{
Laureano Raúl González Ruiz • Alfredo Eduardo Zurita • \\ John Fleagle • Gustavo Juan Scillato-Yané • \\ María Teresa Dozo • Martín Zamorano
}

\begin{abstract}
In this contribution we document the southernmost and probably the oldest record of the tribe Neuryurini (Glyptodontidae). The southernmost record of this tribe outside of Patagonia is Neuryurus sp. from Lujanian sediments (Luján Formation, late Pleistocene-early Holocene) at Quequén Grande River (Buenos Aires Province, Argentina). The first and only previous record of a specimen of the Neuryurini in Patagonia was reported from the upper levels of the Puerto Madryn Formation (Huayquerian SALMA, late Miocene), exposed in Península Valdés (Chubut Province, Argentina). The new specimen described here and assigned to an indeterminate Neuryurini was recovered at Estancia La Peninsular (Santa Cruz Province, Argentina). This locality has been recognized in geological
\end{abstract}

L. R. González Ruiz ( $\square)$

Laboratorio de Investigaciones en Evolución y Biodiversidad (LIEB), Universidad Nacional de la Patagonia "San Juan Bosco" sede Esquel (UNPSJB), Ruta Nacional 259, km 16.5, 9200 Esquel, Chubut, Argentina

e-mail: gonzalezlaureano@yahoo.com.ar

A. E. Zurita

Centro de Ecología Aplicada del Litoral (CECOAL),

y, Universidad Nacional del Nordeste (UNNE),

Ruta 5, km 2.5 CC, 1283400 Corrientes, Argentina

e-mail: azurita@cecoal.com.ar

J. Fleagle

Department of Anatomical Sciences, Health Sciences Center,

Stony Brook University, Stony Brook, NY, USA

e-mail: jfleagle@notes.cc.sunsysb.edu

G. J. Scillato-Yané · M. Zamorano

División Paleontología Vertebrados, Facultad de Ciencias

Naturales, Museo de La Plata, Paseo del Bosque s/n,

1900 La Plata, Argentina

e-mail: scillato@museo.fcnym.unlp.edu.ar studies as part of the Santa Cruz Formation (Santacrucian SALMA, late early Miocene), but there have been no fossils described from this site until now. Therefore, the new specimen represents, with the two confirmed records of Glyptodon Owen and Panochthus Burmeister (both from the Quaternary), the only non-Propalaehoplophorinae glyptodontids reported for Santa Cruz Province.

Keywords Glyptodontidae · Neuryurini · Miocene · Patagonia $\cdot$ Argentina

Kurzfassung In dieser Untersuchung wurde der vielleicht früheste und am südesten berichteten Fund der Tribe Neuryurini (Glyptodontidae) nachgewiesen. Der am

\author{
M. Zamorano \\ e-mail: marzamorano@museo.fcnym.unlp.edu.ar \\ M. T. Dozo \\ Laboratorio de Paleontología, UI Diversidad, Sistemática y \\ Evolución, Centro Nacional Patagónico (CENPAT-CONICET), \\ Puerto Madryn, Argentina \\ e-mail: dozo@cenpat.edu.ar \\ L. R. González Ruiz · A. E. Zurita · G. J. Scillato-Yané · \\ M. T. Dozo - M. Zamorano \\ CONICET, Buenos Aires, Argentina
}


südesten beobachtete Fund dieser Tribe ausserhalb Patagonien ist Neuryurus sp. aus den Lujanian Sedimenten (Formation Luján, spät Pleistozän- früh Holozän), am Fluss Quequén Grande (Provinz Buenos Aires, Argentinien). Der erste und einzige frühere Fund von einem Exemplar von Neuryurini in Patagonien wurde in den höheren Schichten der Formation Puerto Madryn (Huayquerian SALMA, spät Miozän) gefunden, welcher auf der Halbinsel Valdés (Provinz Chubut, Argentinien) ausgestellt ist. Der neue Exemplar hierbei beschrieben, welcher einem noch unbestimmten Neuryurini zugewiesen ist, wurde auf dem Estancia La Peninsular (Provinz Santa Cruz, Argentinien) gefunden. Dieser Raum wurde, anhand von geologischen Untersuchungen, als Teil der Formation Santa Cruz (Santacrucian SALMA, spät-früh Miozän) erkannt. Bis jetzt wurden keine aus diesem Ort stammenden Fossilien beschrieben Aus diesen Gründen bekundet dieser neue Exemplar, zusammen mit den zwei bestätigten Funden von Glyptodon Owen und Panochthus Burmeister (beide aus dem Quartär), der einzige berichtete non-Propalaehoplophorinae Glyptodontids in der Provinz Santa Cruz.

Schlüsselwörter Glyptodontidae - Neuryurini · Miozän · Patagonien · Argentinien

\begin{tabular}{|c|c|}
\hline \multicolumn{2}{|c|}{ Abbreviations } \\
\hline \multirow[t]{2}{*}{$\mathrm{CC}$} & Museo Universitario "Florentino y Carlos \\
\hline & $\begin{array}{l}\text { Ameghino" Universidad Nacional de Rosario } \\
\text { (ex Instituto de Fisiografía y Geología "Alfredo }\end{array}$ \\
\hline \multirow{2}{*}{ FC-DPV } & Facultad de Ciencias Denartamento de \\
\hline & Paleontología (Montevideo, Uruguay) \\
\hline $\mathrm{MACN}$ & $\begin{array}{l}\text { Sección Paleontología Vertebrados, Museo } \\
\text { Argentino de Ciencias Naturales "Bernardino } \\
\text { Rivadavia" (Buenos Aires Province, Argentina) }\end{array}$ \\
\hline MCNL & $\begin{array}{l}\text { Museo de Ciencias Naturales de Lobería } \\
\text { (Buenos Aires Province, Argentina) }\end{array}$ \\
\hline \multirow[t]{3}{*}{ MCNN } & Museo Municipal de Ciencias Naturales de \\
\hline & Necochea "Dr. José Escuadrone" (Buenos \\
\hline & Aires Province, Argentina) \\
\hline \multirow[t]{3}{*}{ MLP } & Museo de La Plata (Facultad de Ciencias \\
\hline & Naturales y Museo Universidad Nacional de \\
\hline & La Plata) (Buenos Aires Province, Argentina) \\
\hline \multirow[t]{2}{*}{ MPCNP } & Museo Provincial de Ciencias Naturales de \\
\hline & Paraná (Entre Ríos Province, Argentina) \\
\hline \multirow[t]{2}{*}{ MPM-PV } & Museo Regional Provincial "Padre Manuel \\
\hline & Jesús Molina” (Santa Cruz Province, Argentina) \\
\hline \multirow[t]{2}{*}{ MPEF } & Museo Paleontológico "Egidio Feruglio" \\
\hline & (Chubut Province, Argentina) \\
\hline UAP & Museo David Rhys, Universidad Adventista \\
\hline & del Plata (Entre Ríos Province, Argentina) \\
\hline $\mathrm{A}$ & South American Land Mammal Age \\
\hline
\end{tabular}

\section{Abbreviations} (ex Instituto de Fisiografía y Geología "Alfredo Castellanos") (Santa Fe Province, Argentina)

\section{FC-DPV Facultad de Ciencias, Departamento de} Paleontología (Montevideo, Uruguay)

MACN Sección Paleontología Vertebrados, Museo Argentino de Ciencias Naturales "Bernardino

MCNL Museo de Ciencias Naturales de Lobería (Buenos Aires Province, Argentina)

Necochea "Dr. José Escuadrone" (Buenos Aires Province, Argentina)

Naturales y Museo Universidad Nacional de Paraná (Entre Ríos Province, Argentina) Jesús Molina" (Santa Cruz Province, Argentina) Museo Paleontológico "Egidio Feruglio" Museo David Rhys, Universidad Adventista del Plata (Entre Ríos Province, Argentina)

South American Land Mammal Age

\section{Introduction}

The cingulatan family Glyptodontidae was one of the most conspicuous among the Cenozoic xenarthrans from South America, with an extensive latitudinal range from approximately $36^{\circ} 37^{\prime} \mathrm{N}$ (Carmen glyptodont fossil locality, northern Oklahoma, USA) (Czaplewski 2004) to $51^{\circ} 34^{\prime} \mathrm{S}$ (Killik Aike Norte, Santa Cruz Province, Argentina) (Scott 1903; Marshall 1976; Tauber et al. 2004). The earliest record of the Glyptodontidae comes from the late Eocene in Patagonia, Argentina, and belongs to the subfamily Glyptatelinae (Ameghino 1902; Kay et al. 1999; Carlini et al. 2005). From this initial record up to the "Friasian" SALMA (middle Miocene), Patagonia has preserved the best evidence for the radiation of the group (Pascual 1984; Pascual and Odreman Rivas 1973; Pascual et al. 1984), as part of a broader and well known radiation of the Cingulata (Scillato-Yané 1986). Moreover, Pascual and Odreman Rivas (1973) and Pascual et al. (1984) have suggested that major radiation and cladogenesis for the Cingulata took place in Patagonia. More recently, other possible evolutionary scenarios have been proposed for the radiation Cingulata, at lower latitudes (see Carlini et al. 2008).

The glyptodontid tribe Neuryurini (?late Miocene-late Pleistocene) is one of the more poorly known groups of cingulatans. The best know taxa are Neuryurus rudis (Gervais) (early-middle Pleistocene, Ensenadan SALMA), N. trabeculatus (Zurita and Ferrero 2009) and Neuryurus sp. (late Pleistocene, Lujanian SALMA), from Argentina (see Ameghino 1889; Gervais 1878; Zurita and Ferrero 2009; Zurita et al. 2006). According to Hoffstetter (1958: 586), the Neuryurini are characterized by the following characters:... "les plaques sont épaisses, souvent rectangulaires, unies par sutures indentées, mais lâches; la surface externe est uniformément perforée...Le bouclier céphalique rappelle quelque peu Panochthus Burmeister, 1866 par la présence de tubercules peu marqués."

In this contribution we present the southernmost and probably the oldest record of a Neuryurini glyptodont. This is one of the rare records of a non-Propalaehoplophorinae glyptodontid from Patagonia.

\section{The record of the Neuryurini in Patagonia}

Dozo et al. (2002, 2008) reported the first and only Neuryurini from Patagonia represented by one isolated osteoderm and assigned by them to Neuryurini gen. et sp. indet. (MPEF-PV 2533) (Figs. 1a, 9 and 2c). This specimen comes from the upper levels of the Puerto Madryn Formation exposed in Península Valdés (specifically from 
Fig. 1 a Geographic distribution of the Glyptodontidae Neuryurini. 1 Neuryurus sp. (Lobería, Buenos Aires Province), 2 Neuryurus sp. (Punta San Andrés, Buenos Aires Province), 3 Neuryurus trabeculatus (Arroyo Ensenada, Entre Ríos Province), 4 Pseudoeuryurus lelongianus (Paraná, Entre Ríos Province), 5 Neuryurus sp. (Uquía, Jujuy Province), 6 Urotherium (Valle de Santa María, Catamarca Province), 7 Neuryurus cf. $N$. rudis (Artigas, Salto, and Tacuarembó departments, northern Uruguay), 8 Neuryurus sp. (Río Grande do Sul, southern Brazil), 9 Neuryurini gen. et sp. indet. (Punta Delgada, Península Valdés, Chubut Province), 10 Neuryurini gen. et sp. indet. (Estancia La Peninsular, Santa Cruz Province). b Detail of the location map of Estancia La Peninsular locality, Santa Cruz Province, Argentina

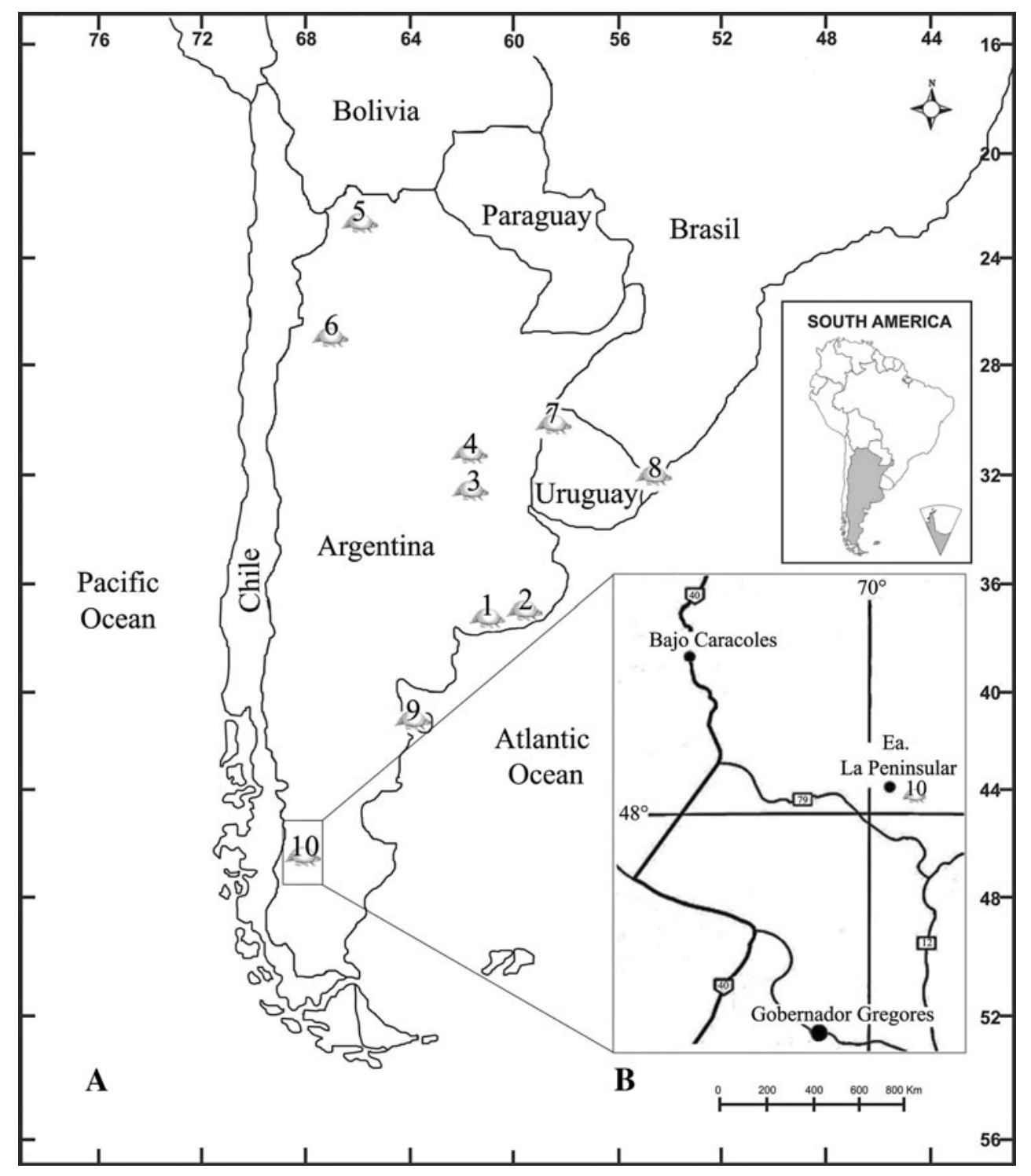

Rincón Chico near Punta Delgada, northeastern Chubut Province); associated fossil vertebrates indicate the Huayquerian SALMA (late Miocene) for these sediments. ${ }^{40} \mathrm{~K} /{ }^{39}$ Ar dates were obtained from a tuff in the upper part of the marine Rionegran, in Bahía Cracker (Chubut Province), with an age averaging 9.41 Ma (Zinsmeister et al. 1981). Recently Scasso et al. (2001) presented several dates obtained by ${ }^{87} \mathrm{Sr} /{ }^{86} \mathrm{Sr}$ from bivalves, giving an average age of 10.1 Ma. From a paleoenvironmental point of view, the fossiliferous levels represent the terminal regressive phase of the Tertiary Sea, and the transition to a continental environment (Dozo et al. 2008). Thus, this is the first evidence of late Miocene continental vertebrates south of Río Negro Province, and until now the only report of the tribe Neuryurini in Patagonia.

\section{The new Neuryurini specimen}

\section{Systematic paleontology}

Order Cingulata Illiger, 1811

Superfamily Glyptodontoidea Gray, 1869

Family Glyptodontidae Gray, 1869

Subfamily Hoplophorinae Huxley, 1864

Tribe Neuryurini Hoffstetter, 1958

Neuryurini gen. et sp. indet.

Figure $2 \mathrm{a}, \mathrm{b}$ 


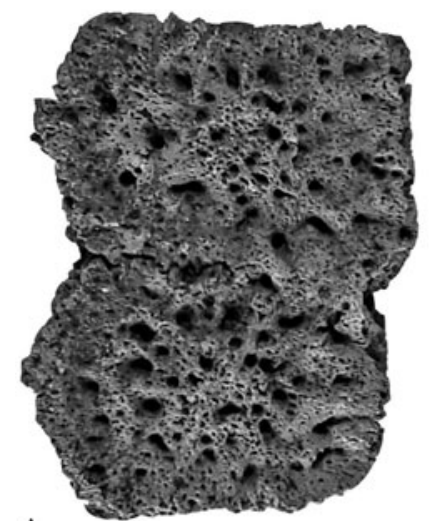

A

B
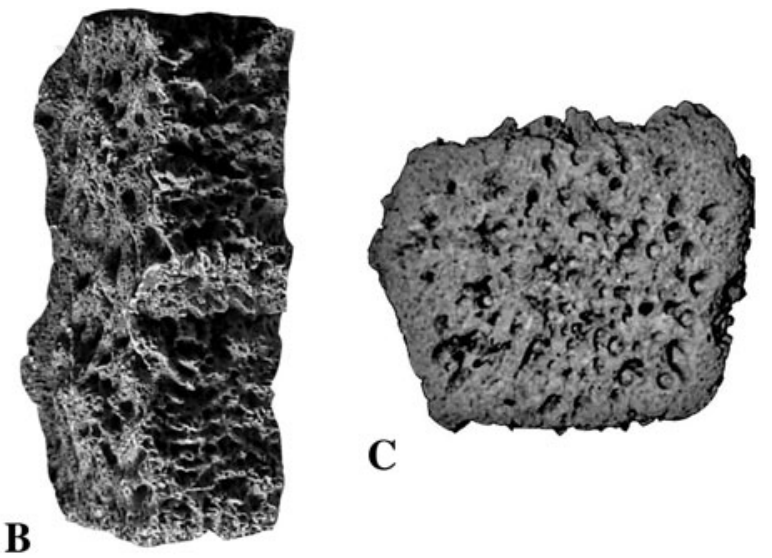

$\mathbf{C}$

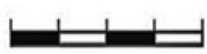

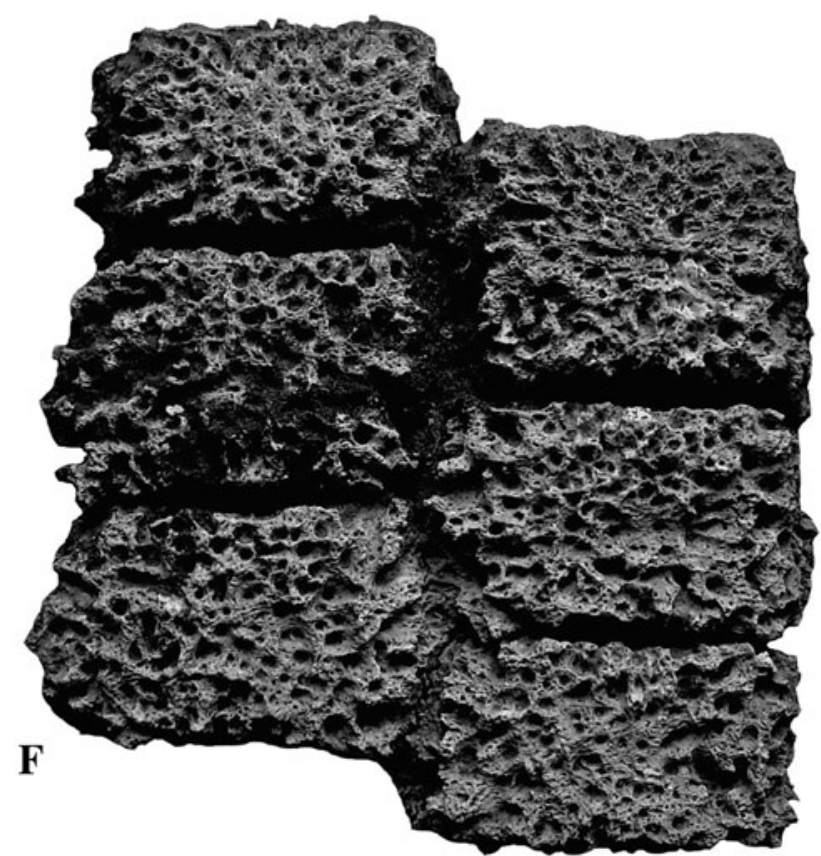

modified from Ameghino 1889), one osteoderm in dorsal view. e Neuryurus sp. (MCNL 6.6), four osteoderms in dorsal view. f Neuryurus trabeculatus (UAP 1510), six osteoderms in dorsal view. Scale bar $2 \mathrm{~cm}$

clasts, maximum diameter variable $1-4 \mathrm{~cm}$. These strata are about $20 \mathrm{~m}$ thick, followed by about $10 \mathrm{~m}$ of claystone and siltstones, gray to yellowish.

The osteoderms were a surface find, recovered from the surface of eroded siltstone badlands during the course of prospecting for vertebrate fossils. While it is not possible to determine exactly where they derived from, there is no good reason to belive they did not erode from the adjacent sediments.

The sediments at Estancia La Peninsular were assigned by de Barrio et al. $(1982,1984)$ to the Santa Cruz Formation, Santacrucian SALMA (late early Miocene), an allocation also supported by Panza and Cobos (2001). Nevertheless, these authors did not report on any vertebrate 
fossils collected at this particular locality, although many vertebrate fossils have been recovered from other, scattered sedimentary deposits in the region (Bown and Fleage 1993; de Barrio et al. 1984; Rae et al. 1996). Because the tribe Neuryurini has not been reported from any of the very extensive Santacrucian (late early Miocene) and "Friasian" (middle Miocene) deposits from the Santa Cruz, Chubut, Río Negro, or Neuquén provinces, there is also the possibility of younger sediments at La Peninsular that have not been recognized. Further geological and paleontological research in this area is clearly warranted.

\section{Description}

The material consists of two articulated osteoderms from the dorsal carapace, pentagonal in shape, and well preserved (Fig. 2a, b). The larger has a length of $41 \mathrm{~mm}$, a width of $25.2 \mathrm{~mm}$, and a thickness of $14.7 \mathrm{~mm}$ (including the central elevation). A comparison with the osteoderms of Neuryurus Ameghino suggests that these may correspond to the lateral region of the dorsal carapace (Fig. 2a, $\mathrm{e}, \mathrm{f})$. The exposed surface is characterized by a remarkable roughness (more than in Neuryurus and Pseudoeuryurus Ameghino and much more than in Urotherium Castellanos) and in having numerous foramina. The central area, elevated and with smaller foramina, is surrounded by a row of foramina of greater diameter, as has been observed, to a lesser degree, in several osteoderms of Neuryurus. Unlike $P$. lelongianus Ameghino, this central region does not present a middle concavity (Fig. 2d). As in Neuryurus, most of the conduits penetrate in a nearly oblique angle. The articular area is denticular, and the sutures are visible, similar to that observed in Neuryurus trabeculatus (Fig. 2f).

In sum, the morphology of these osteoderms shows a considerable similarity with those of Neuryurus (e.g., MCNL 6.6, MCNN s/n, MLP 07-V-3-1, FC-DPV 901) and with the osteoderm presented by Dozo et al. (2008) (Fig. 2c), although in this case the exhibited surface has undergone some erosion (length $36.75 \mathrm{~mm}$, width $28.95 \mathrm{~mm}$, thickness $12.21 \mathrm{~mm}$ ).

\section{The record of extra-Patagonian Neuryurini}

Based on the evidence discussed above, and accepting that Pseudoeuryurus and Urotherium are Neuryurini, the first record of this tribe probably corresponds to Pseudoeryurus lelongianus Ameghino (Figs. 1a, 4 and 2d) and Urotherium interundatum (Ameghino) from the Mesopotamian (late Miocene-Pliocene), of the Mesopotamian region of Argentina $\left(30^{\circ}-33^{\circ} \mathrm{S}\right.$ and $\left.60^{\circ}-58^{\circ} \mathrm{W}\right)$, and to Urotherium simile Castellanos from the Araucanian (late Miocene-Pliocene) of the northwest of Argentina $\left(28^{\circ}-26^{\circ} \mathrm{S}\right.$ and $68^{\circ}-65^{\circ} \mathrm{W}$ ) (see Ameghino 1885, 1889; Castellanos 1948) (Fig. 1a). In this context, the first record of a Neuryurini in the Pampean region corresponds to Urotherium antiquus (Ameghino), of the Montehermosan SALMA (late Miocene-Pliocene). The Neuryurini (Urotherium spp.) are also recorded in the Chapadmalalan and Marplatan SALMAs (Pliocene) of the Pampean region of Argentina, although they are very scarce (Scillato-Yané et al. 1995). From the late Pliocene to the late Pleistocene, the Neuryurini $[N$. rudis, $N$. trabeculatus (Fig. 1b, 3 and 2f) and Neuryurus sp. (Fig. 1b, 1 and 2e)] extended their distribution remarkably, with an area that ranges from $38^{\circ} \mathrm{S}$ to $28^{\circ} \mathrm{S}$ and from $60^{\circ} \mathrm{W}$ to approximately $53^{\circ} \mathrm{W}$ (Ameghino 1889; Ubilla et al. 2004; Zurita et al. 2009) (Fig. 1a).

\section{Discussion and conclusions}

The phylogeny, taxonomy, and paleobiogeography of glyptodonts, especially for those from the southernmost region of South America are still poorly understood (Carlini et al. 2008; Croft et al. 2007; Fernicola 2008). Nevertheless, the significant record during most of the time interval from late early Miocene to middle Miocene permits a reasonable understanding of some lineages of the Glyptodontidae.

The Glyptodontidae are first recorded from Paleogene outcrops of Gran Barranca (central Patagonia) with records of the Glyptatelinae from levels tentatively assigned to the Tinguirirican SALMA (late Eocene-early Oligocene) (Carlini et al. 2005) and the Propalaehoplophorinae from Deseadan SALMA (early Oligocene) (Scillato-Yané 1977).

The Neogene started with a high diversity of Propalaehoplophorinae during the Santacrucian SALMA (late early Miocene) (McKenna and Bell 1997; Scillato-Yané 1986). In that context recently Croft et al. (2007) mentioned that the Propalaehoplophorinae are of uncertain monophyly and Fernicola $(2006,2008)$ has proposed that they are a natural group.

During the "Friasian" SALMA (Friasian s.s., Colloncuran s.s., and Mayoan), other new lineages of Glyptodontidae evolution appeared, principally represented by Palaehoplophorini (Hoplophorinae) (Ameghino 1904; Kraglievich 1930), Glyptodontidae incertae sedis (ScillatoYané and Carlini 1998; Zurita 2007), and a probably new glyptodont Propalaehoplophorinae (González Ruiz et al. 2010), with the Propalaehoplophorinae also recorded (Kraglievich 1930; Roth 1899).

Later, the Chasicoan, Huayquerian, and Montehermosan SALMAs (late Miocene-early Pliocene) marked the disappearance of the Pan-Santacrucian elements, still present in the Chasicoan (late Miocene) (see Bondesio et al. 1980; 
Pascual and Ortiz Jaureguizar 1990; Scillato-Yané 1977, 1979). In this time range, the Glyptodontidae underwent an important radiation with the diversification of Hoplophorinae (Palaehoplophorini, Hoplophorini, and Plohophorini), Doedicurinae, and Glyptodontinae (Scillato-Yané 1986).

In this scenario, the first possible Neuryurini appeared in the fossil record during this time with several taxa, Pseudoeuryurus lelongianus Ameghino (Ameghino 1889), Urotherium antiquus, $U$. interundatus, and $U$. simile Castellanos (Castellanos 1926), recorded between $26^{\circ} \mathrm{S}$ and $33^{\circ} \mathrm{S}$. Recently, Dozo et al. (2008) presented the southernmost record of a Neuryurini, coming from the Puerto Madryn Formation (late Miocene), northeastern coast of Chubut Province. During the Pleistocene, the Neuryurini (Neuryurus spp.) extended their geographic distribution to the north and east but were always restricted to the south end of South America.

Therefore, the new specimen described in the present work is the southernmost Neuryurini discovered up to now $\left(47^{\circ} 43^{\prime} 35.2^{\prime \prime} \mathrm{S}\right)$, and together with the three mentioned records of Quaternary Glyptodontidae, one of Glyptodon clavipes and two of Panochtus sp. (Ameghino 1900-1902; Parodi 1930; Tauber and Palacios 2007; Tauber pers. com. to LRGR 2009), documents the most extreme austral distribution of non-Propalaehoplophorinae glypdonts. If the Santacrucian SALMA of this new specimen is confirmed, it will be the oldest record of a Neuryurini and could reveal a greater Glyptodontidae diversification than supposed, since the only recorded Patagonian glyptodonts for this time period (late early Miocene) are the Propalaehoplophorinae. This would corroborate the hypothesis of Fernicola (2008) who has suggested an early first splitting within the Glyptodontidae during the Colhuehuapian SALMA, or even before, during the Deseadan SALMA. Finally, and based on the current evidence, the Hoplophorinae Neuryurini appears to be a group of Glyptodontidae restricted to the southern part of South America.

Acknowledgments The authors wish to thank M. Reguero and L. Pomi (MLP), A. Kramarz and J. Fernicola (MACN) for allowing access to paleontological collections under their care; M. Perkins, S. Pintos, and F. Degrange for their help in the field; A. Tauber for his information about the Quaternary glyptodonts; M. Tejedor and G. Martin for their helpful comments on the manuscript; Adan A. Tauber for some information about glyptodonts from Patagonia; Germán Gasparini for the translation of the abstract; and an anonymous reviewer whose suggestions improved our manuscript. This work was supported by grant PICT-SECYT 07/32344 to M.T.D. Fieldwork was funded by a grant from the National Geographic Society to J.G.F.

\section{References}

Ameghino, F. 1885. Nuevos restos de mamíferos fósiles oligocenos recogidos por el Profesor Pedro Scalabrini y pertenecientes al
Museo Provincia de la ciudad de Paraná. Boletín de la Academia Nacional de Ciencias 8: 5-207.

Ameghino, F. 1889. Contribución al conocimiento de los mamíferos fósiles de la República Argentina. Actas de la Academia Nacional de Ciencias de Córdoba 6: 1-1027.

Ameghino, F. 1900-1902. L'age des formations sédimentaires de Patagonie. Anales de la Sociedad Cientifica Argentina 50: 109-130,145-165, 207-229 (1900); 51: 20-39, 65-91 (1901); 52: 189-197, 244-250 (1901); 54: 161-180, 220-240, 283-342 (1902).

Ameghino, F. 1902. Notices préliminaires sur des mammifères nouveaux des terrains crétacés de Patagonie. Boletín de la Academia Nacional de Ciencias en Córdoba 17: 5-70.

Ameghino, F. 1904. Nuevas especies de mamíferos cretáceos y terciarios de la República Argentina. Anales de la Sociedad Cientifica Argentina 58: 35-41; 56-71; 182-192; 225-291.

Bondesio, P., J. Rabassa, R. Pascual, M.G. Vucetich, and G.J. Scillato-Yané. 1980. La Formación Collón-Curá de Pilcaniyeu Viejo y sus alrededores (Río Negro, República Argentina). Su antigüedad y las condiciones ambientales según su distribución, su litogenésis y sus vertebrados. Actas $2^{\circ}$ Congreso Argentino de Paleontología y Bioestratigrafía y $1^{\circ}$ Congreso Latinoamericano de Paleontología 3: 85-9.

Bown, T.M., and J.G. Fleagle. 1993. Systematics, biostratigraphy, and dental evolution of the Palaeothentidae, Later Oligocene to Early-Middle Miocene (Deseadan-santacrucian) caenolestoid marsupials of South America. Journal of Paleontology 67: 1-76.

Carlini, A.A., M. Ciancio, and G.J. Scillato-Yané. 2005. Los Xenarthra de Gran Barranca: más de 20 Ma de historia. Actas $16^{\circ}$ Congreso Geológico Argentino: 419-242.

Carlini, A.A., A.E. Zurita, G.J. Scillato-Yané, R. Sánchez, and O. Aguilera. 2008. A new glyptodont species from Codore Formation (Pliocene), Estado Falcón (Venezuela), and the Asterostemma' problem. Paläontologische Zeitschrift 82(2): 139-152.

Castellanos, A. 1926. Sobre un nuevo gliptodóntido chapadmalense. Urotherium simplex $n$. gen. $n$. sp. y las formas afines. Anales del Museo Nacional de Histria Natural Bernardino Rivadavia 60: 263-278.

Castellanos, A. 1948. La presencia del género Urotherium en el Araucanense del Valle del Yocavil (Santa María), provincias de Catamarca y Tucumán. Publicaciones del Instituto de Fisiografía y Geología (Facultad de Ciencias Matemáticas, Físicoquímicas y Naturales. Universidad Nacional del Litoral) 35: $1-16$.

Croft, D.A., J.J. Flynn, and A.R. Wyss. 2007. A new basal glyptodontid and other Xenarthra of the early Miocene Chucal fauna, northern Chile. Journal of Vertebrate Paleontology 27(4): 781-797.

Czaplewski, J. 2004. A glyptodont (Mammalia: Xenarthra) from northern Oklahoma. Oklahoma Geology Notes 64(1-4): 1-10.

de Barrio, R.E., O.G. Arrondo, A.E. Artabe, and B. Petriella. 1982. Estudio geológico y paleontológico de los alrededores de la Estancia Bajo Pellegrini, Provincia de Santa Cruz. Revista de la Asociación Geológica Argentina 37(3): 285-299.

de Barrio, R.E., G.J. Scillato-Yané, and M. Bond. 1984. La Formación Santa Cruz en el borde occidental del macizo del Deseado (Provincia de Santa Cruz) y su contenido paleontológico. Actas $9^{\circ}$ Congreso Geológico Argentino 4: 539-556.

Dozo, M.T., A. Monti, P. Bouza, M.G. Vucetich, A.L. Cione, E.P. Tonni, and G.J. Scillato-Yané. 2002. Geología y vertebrados continentales en cercanías de Punta Delgada (Neógeno de Península Valdéz, Chubut, Argentina). Actas $15^{\circ}$ Congreso Geológico Argentino: 1-7.

Dozo, M.T., P. Bouza, C. Tambussi, and G. Massaferro. 2008. Vertebrados continentales de Edad Huayqueriense (Mioceno tardío) en Península Valdés (Chubut, Argentina): implicancias 
biocronológicas, paleoambientales y paleobiogeográficas. Resúmenes $3^{\circ}$ Congreso Latinoamericano de Paleontología de Vertebrados: 83.

Fernicola, J.C. 2006. Análisis filogenético de la subfamilia Propalaehoplophorinae Ameghino, 1891. Ameghiniana 43 (4): 37R$38 \mathrm{R}$.

Fernicola, J.C. 2008. Nuevos aportes para la sistemática de los Glyptodontia Ameghino 1889 (Mammalia, Xenarthra, Cingulata). Ameghinana 45(3): 553-574.

Gervais, H. 1878. Nouvelles recherches sur les mammifères fossiles propres á 1 Amérique méridionale. Comptes Rendus de l'Académie des Sciences 86(22): 1359-1362.

González Ruiz, L.R., A.E. Zurita, G.J. Scillato-Yané, and M. Zamorano. 2010. Un nuevo Glyptodontidae Gray, 1869 (Mammalia: Xenarthra: Cingulata) del Mioceno medio de Patagonia central, Argentina. Reunión Anual de Comunicaciones de la Asociación Paleontológica Argentina y Conferencias: Darwin, Lamarck y la teoría de la evolución de las especies. Ciudad Autónoma de Buenos Aires, Argentina. Libro de resúmenes y actividades: $50-51$.

Hoffstetter, R. 1958. Xenarthra. In Traité de Paléontologie, ed. J. Piveteau, 535-636. Paris: Masson et Cie.

Kay, F.R., R.H. Madden, M.G. Vucetich, A.A. Carlini, M.M. Mazzoni, G.H. Re, M. Heizler, H. Sandeman, and R.L. Cifelli. 1999. Revised age of the Casamayoran South American Land Mammal Age: climatic and biotic implications. Proceedings of the National Academy of Sciences 96(23): 13235-13240.

Kraglievich, L. 1930. La Formación Friaseana del río Frias, río Fénix, Laguna Blanca, etc., y su fauna de mamíferos. Physis 10(35): 127-161.

Marshall, L.G. 1976. Fossil localities for Santacrucian (Early Miocene) mammals, Santa Cruz Province, Southern Patagonia, Argentina. Journal of Paleontology 50(6): 1129-1142.

McKenna, M.C., and S.K. Bell. 1997. Classification of Mammals Above the Species Level. New York: Columbia University Press.

Panza, J.L., and J.C. Cobos. 2001. Hoja Geológica 4769-III. Destacamento La María. Provincia de Santa Cruz. Boletín Servicio Geológico Minero Argentino 296: 1-81.

Parodi, L.J. 1930. Sobre nuevos restos de mamíferos de la fauna pampeana en Patagonia. Physis 10: 21-34.

Pascual, R. 1984. La sucesión de las Edades mamíferos, de los climas y del diastrofismo sudamericano durante el Cenozoico: fenómenos concurrentes. Anales de la Academia Nacional de Ciencias Exactas, Físicas y Naturales 36: 15-37.

Pascual, R., and O.E. Odreman Rivas. 1973. Las unidades estratigráficas del Terciario portadoras de mamíferos. Su distribución y sus relaciones con fenómenos diastróficos. Anales $5^{\circ}$ Congreso Geológico Argentino 3: 139-156.

Pascual, R., and E.O. Ortiz Jaureguizar. 1990. Evolving climates and mammal faunas in Cenozoic South America. Journal of Human Evolution 19: 23-60.

Pascual, R., P. Bondesio, M.G. Vucetich, G.J. Scillato-Yané, M. Bond, and E.P. Tonni. 1984. Vertebrados fósiles cenozoicos. Relatorio $9^{\circ}$ Congreso Geológico Argentino 2 (9): 539-561.

Rae, T.C., T.M. Bown, and J.C. Fleagle. 1996. New palaeothentid marsupials (Caenolestoidea) from Early Miocene of Patagonian Argentina. American Museum Novitates 3165: 1-10.

Roth, S. 1899. Apuntes sobre la geología y la paleontología de los territorios del Río Negro y Neuquén. Revista del Museo de La Plata 9: 141-172.
Scasso, R.A., J.M. McArthur, C.J. del Río, S. Martínez, and M.F. Thirlwall. 2001. ${ }^{87} \mathrm{Sr} /{ }^{86} \mathrm{Sr}$ Late Miocene age of fossil molluscs in the Entrerriense of the Valdez Peninsula (Chubut, Argentina). Journal of South American Earth Sciences 14: 229-319.

Scillato-Yané, G.J. 1977. Sur quelques Glyptodontidae nouveaux (Mammalia, Edentata) du Déséadien (Oligocéne inférieur) de Patagonie (Argentine). Bulletin du Muséum National d'Histoire Naturelle 487: 249-260.

Scillato-Yané, G.J. 1979. Nota sobre los Dasypodidae (Mammalia, Edentata) del Plioceno del territorio argentino. Los restos de edad Chasiquense (Plioceno inferior) del sur de la provincia de Buenos Aires. Ameghiniana 14(1-4): 133-144.

Scillato-Yané, G.J. 1986. Los Xenarthra fósiles de Argentina (Mammalia, Edentata). Actas $7^{\circ}$ Congreso Argentino de Paleontología y Bioestratigrafía: 151-155.

Scillato-Yané, G.J., and A.A. Carlini. 1998. Nuevos Xenarthra del Friasense (Mioceno Medio) de Argentina. Studia Geologica Salmantisencia 34: 43-67.

Scillato-Yané, G.J., A.A. Carlini, S.F. Vizcaíno, and E. Ortiz Jaureguizar. 1995. Los Xenarthros. In Evolución biológica y climática de la región Pampeana durante los últimos cinco millones de años. Un ensayo de correlación con el Mediterráneo occidental, eds. M.T. Alberdi, G. Leone and E.P. Tonni, 183-209. Madrid: Museo de Ciencias Naturales, Consejo de Investigaciones, Monografías CSIC.

Scott, W.B. 1903. Glyptodonta and Gravigrada. In Reports of the Princeton University Expeditions to Patagonia, 1896-1899, ed. W.B. Scott, 107-277. Princeton and Stuttgart: Princeton University and E. Schweizerbart'sche Verlagshandlung (E. Nägele).

Tauber, A.A., and M.E. Palacios. 2007. Nuevo registro de mamíferos cuaternarios de gran porte en la provincia de Santa Cruz, República Argentina. Ameghinana 44(4): 41R.

Tauber, A.A., R.F. Kay, C. Luna, and M.E. Palacios. 2004. Aspectos paleoambientales de la Formación Santa Cruz (Mioceno Temprano-Medio) en Killik Aike Norte, Patagonia, Argentina. Ameghinana 41(4): 20R.

Ubilla, M., D. Perea, C.G. Aguilar, and N. Lorenzo. 2004. Late Pleistocene vertebrate from northern Uruguay: tools for biostratigraphic, climatic and environmental reconstruction. Quaternary International 114: 129-142.

Zinsmeister, W.J., L.G. Marshall, R.E. Drake, and G.H. Curtis. 1981. First radioisotope (potassium-argon) age of marine Neogene Rio Negro beds in northeastern Patagonia, Argentina. Science 212: 440.

Zurita, A.E. 2007. Sistemática y evolución de los Hoplophorini (Xenarthra, Glyptodontidae, Hoplophorinae. Mioceno tardíoHoloceno temprano). Importancia bioestratigráfica, paleobiogeográfica y paleoambiental. Tesis doctoral, Universidad Nacional de la Plata, 367 pp.

Zurita, A.E., and B. Ferrero. 2009. A new species of Neuryurus Ameghino (Mammalia, Glyptodontidae) from the late Pleistocene of the Mesopotamic region of Argentina. Geobios 42: $663-673$.

Zurita, A.E., E. Soibelzon, and A.A. Carlini. 2006. Neuryurus (Xenarthra, Glyptodontidae) in the Lujanian (late Pleistoceneearly Holocene) of the Pampean region. Neues Jahrbuch für Geologie und Paläontologie 2: 78-88.

Zurita, A.E., E. Soibelzon, G.J. Scillato-Yané, and M. Cenizo. 2009. The earliest record of Neuryurus Ameghino (Mammalia, Glyptodontidae, Hoplophorinae). Alcheringa 33: 32-37. 